\title{
"What Should His Sufferance Be?" Protesting Injustice in Shakespeare's Venice and the Age of Black Lives Matter
}

\author{
JESSICA WALKER
}

This essay considers the impossibility faced by The Merchant of Venice's Shylock in seeking redress for his suffering and how dismissal of his complaints parallels criticism of protests against racial injustice in the twenty-first century, with particular attention to Colin Kaepernick's 2016 protest against police brutality. Venice's idealization of Christ-like passivity and our own age's veneration of Martin Luther King Jr.'s nonviolence create impossible standards for those attempting to call attention to injustice, leading to condemnation of protesters' actions and misinterpretation of their motives.

In 2016, Colin Kaepernick, a professional football player for the San Francisco 49ers, refused to stand for the national anthem during games in protest at police violence against the black community. As protests go, Kaepernick's was as nonconfrontational as one could conceivably be; he did not riot, strike, march, or even speak. Like those who occupied lunch counters and bus seats before him, he simply sat, a gesture unobtrusive enough that it went unnoticed the first two times he did it. Later, after an exchange with a veteran and fellow athlete, Kaepernick began to kneel during the anthem rather than sit, to show respect for members of the armed forces while still continuing his protest. ${ }^{\mathrm{I}, 2}$ In response, "vendors sold shirts with Kaepernick's image in the sites of a rifle scope" and "fans took out their anger on a tackling

Department of English, University of North Georgia. Email: jessica.walker@ung.edu.

${ }^{I}$ Nate Boyer, "An Open Letter to Colin Kaepernick, from a Green Beret-Turned-Long Snapper," Army Times, 30 Aug. 2016, at www.armytimes.com/articles/nate-boyer-colinkaepernick-commentary-flag-national-anthem-protest-nfl.

${ }^{2}$ Will Brinson, "Here's How Nate Boyer Got Colin Kaepernick to Go from Sitting to Kneeling," CBS Sports, 27 Sept. 2016, at www.cbssports.com/nfl/news/heres-how-nateboyer-got-colin-kaepernick-to-go-from-sitting-to-kneeling. 
dummy wearing a Kaepernick jersey"; ${ }^{3}$ he was blamed for a dip in the NFL's ratings; ${ }^{4}$ and even Ruth Bader Ginsberg initially called his protest "dumb and disrespectful."' Kaepernick is now an unsigned free agent, the subject of much debate and speculation as to whether the NFL "is denying Colin Kaepernick employment not because he isn't 'good enough' but because he is being shut out for the crime of using his platform to protest the killing of black kids by police." ${ }^{6}$ Meanwhile, the act of kneeling in protest has continued to spread throughout professional football, resulting in an NFL policy that players and teams can be fined for refusal to stand during the national anthem. ${ }^{7}$

In November 2016, Tomi Lahren, a white conservative commentator known for controversial views such as comparing the Black Lives Matter movement to the KKK, appeared on Comedy Central's satirical news program The Daily Show. Much of the interview concerned Lahren's criticism of Kaepernick's protest; she states that he "went about it the wrong way." In response, the program's host, Trevor Noah, a multiracial South African comedian who grew up under apartheid, asked,

What is the right way? So here is a black man in America who says, I don't know how to get a message across. If I march in the streets, people say I'm a thug. If I go out and I protest, people say that it's a riot. If I bend down on one knee - what is the right way? That is something I've always wanted to know. What is the right way for a black person to get attention in America?... How should a black person bring up their grievances? ... I just want to know if you've ever thought of the how. ${ }^{8}$

In Noah's repeated (and unanswered) query, one might hear Shakespeare's Shylock asking, in response to the persecution he faces as a member of Venice's Jewish community, "If a Christian wrong a Jew, what should his

${ }^{3}$ Mike Groll, "Colin Kaepernick Kneels for National Anthem amid 'USA' Chants," CBS News, 6 Oct. 2016, at www.cbsnews.com/news/colin-kaepernick-kneels-for-nationalanthem-amid-crowds-usa-chants.

${ }^{4}$ Daniel Roberts, "Yes, Colin Kaepernick Is Hurting NFL Ratings," Yahoo! News, 8 Dec. 2016, at www.yahoo.com/news/yes-colin-kaepernick-is-hurting-nfl-ratings- 1 8453 I $36 \mathrm{I} \cdot \mathrm{html}$.

5 Nick Wagoner, "Ruth Bader Ginsburg Says National Anthem Protests Are 'Really Dumb," ESPN, Iо Oct. 2016, at www.espn.com/nfl/story/_/id/17763208/ruth-baderginsburg-supreme-court-justice-says-colin-kaepernick-national-anthem-protests-really-dumb.

6 Dave Zirin, "The NFL's War against Colin Kaepernick," The Nation, 8 June 201 7, at www. thenation.com/article/nfls-war-colin-kaepernick.

7 Austin Knoblauch, "NFL Expected to Enact National Anthem Policy for ' 1 8," NFL, 23 May 20I 8, at www.nfl.com/news/story/oap3000000933952/article/nfl-expected-to-enactnational-anthem-policy-for- 18 .

8 Tomi Lahren, interview with Trevor Noah, "Exclusive: Tomi Lahren Extended Interview," The Daily Show, 30 Nov. 2016, at www.cc.com/video-clips/m9ds7s/the-daily-show-withtrevor-noah-exclusive---tomi-lahren-extended-interview. 
sufferance be?"9 Shylock's answer - "Why, revenge" - does not sit well with many readers, however much we sympathize with his plight. ${ }^{10}$ But just as Lahren never answers Noah's question, the play does not adequately answer Shylock's: if cutting out Antonio's heart is the wrong way to seek justice, what is the right way? In considering the impossibility of voicing dissent and seeking redress in The Merchant of Venice, parallels emerge between Shakespeare's play and how we respond in our own time to racial injustice and civil disobedience.

The question of human worth, in both moral and economic senses, pervades The Merchant of Venice; likewise, the current era of civil protest has gathered under the banner of "Black Lives Matter," a slogan that demands recognition of the value of black lives in a country that devalues them. Morocco's offer to "make incision for your love, / To prove whose blood is reddest" ${ }_{11}$ and Shylock's plea "If you prick us, do we not bleed?" ${ }^{2}$ indicate both men's willingness, at least metaphorically, to open their own veins in hopes of proving their worth as human beings. Yet Shylock learns that a single drop of Christian blood holds more value than his dignity, faith, autonomy, and possessions, just as incidents of property damage or minor injury are used to condemn protest, with no concern for the lives the protest seeks to center (as demonstrated by the sardonic hashtag "\#LimoLivesMatter" in the wake of protests at Trump's inauguration). ${ }^{13}$ In their struggle to have their humanity recognized by the state, both Shylock and Kaepernick encounter the same barrier: their cultures' tendency to invoke an idealized image of how the oppressed should behave in response to oppression, embodied by the figures of Jesus Christ and Martin Luther King Jr. respectively. Their radical acts of resistance erased, Christ and King become passively suffering icons, held up as examples to whom Shylock and Kaepernick are unfavorably compared in order to dismiss their complaints.

In Merchant, Antonio's "vulnerable Christ-child" is contrasted with Shylock's "predatory Jew": ${ }^{14}$ with Bassanio and Portia all too ready to come to his aid, the play allows Antonio to garner admiration as the sacrificial lamb without having to be sacrificed, while Portia calls upon Shylock to show Christ-like mercy to his enemies. In our own age, Martin Luther King Jr. has been turned into a similar icon of passive acceptance. King himself

9 William Shakespeare, The Merchant of Venice, in The Riverside Shakespeare, ed. G. Blakemore Evans and J. J. M. Tobin, 2nd edn (Boston, MA: Houghton Miffin Company, 1997), 288-317, 3.1.69-70. I0 Ibid., 3.1.71. ${ }_{11}$ Ibid., 2.2.7.

12 Ibid., 3.1.64.

13 “\#LimoLivesMatter," https://twitter.com/search?q=\%23 LimoLivesMatter.

${ }^{14}$ James O'Rourke, "Racism and Homophobia in The Merchant of Venice," ELH, 70, 2 (Summer 2003), 375-97, 384. 
invited comparisons to Christ, declaring, "If I had to die tomorrow morning I would die happy because I've been to the mountaintop" Is and "It may get me crucified. I may die," " 6 and "offer[ing] himself up for arrest on Good Friday 1963." 17 In the days following his assassination, public figures such as Ralph Abernathy, Pope Paul VI, and Governor Rockefeller compared his death to the crucifixion; ${ }^{18}$ there were even calls to have him canonized. ${ }^{19}$ In the time since, King's image has been invoked to condemn the very resistance he advocated, his message of nonviolence twisted into one of passivity by right-wing figures such as Ron Paul and Glenn Beck. ${ }^{20}$ King's hope for a world in which his children "will not be judged by the color of their skin but by the content of their character" has been appropriated repeatedly as a call to end affirmative action, ${ }^{21}$ while pundits cite his example to condemn rioting in the wake of police violence. ${ }^{22}$ (Often in response to events commemorating King - or, more recently, when his nonviolence has been cited to condemn rioting - left-leaning publications seek to draw attention to his radical, anticapitalist, antiwar politics. ${ }^{23}$ )

The defeat of Shylock, the rewriting of King's legacy, and the willful misinterpretation of Kaepernick's actions reflect similar patterns of public resistance followed by erasure and misinterpretation. Shylock employs some of the same techniques of successful social-justice movements: a clear airing of grievances and explicit demands for justice, stated before influential people in public spaces. In his very first appearance, he cites specific allegations towards Antonio that could serve as a warning to treat Shylock better or face the consequences, and Bassanio, at least, seems to pick up on the implied threat, urging Antonio against the deal. ${ }^{24}$ Shylock's famous "Hath not a Jew eyes?" speech is not a soliloquy by one lamenting his suffering to himself, but rather a litany of

is Martin Luther King Jr. quoted in Scott W. Hoffman, "Holy Martin: The Overlooked Canonization of Dr. Martin Luther King, Jr.," Religion and American Culture: A Journal of Interpretation, I O, 2 (Summer 2000), I 23-48, I 28.

${ }^{16}$ King qtd. in Hoffman, $130 . \quad{ }^{17}$ Hoffman, I30. ${ }^{18}$ Ibid., I $32 . \quad{ }^{19}$ Ibid., 137.

${ }^{20}$ John Avlon, "The MLK Whitewash," Daily Beast, 6 Jan.20 I 2, at www.thedailybeast.com/ articles/201 2/01/16/martin-luther-king-jr-a-communist-why-he-s-been-whitewashed.html.

${ }^{21}$ Paul Rockwell, “The Right Has a Dream," Fair, I May 1995, http://fair.org/extra/the-righthas-a-dream.

${ }^{22}$ Chauncey DeVega, "Dear White America: Please Stop Talking about Martin Luther King Jr. and the Baltimore 'Riots'," DailyKos, 28 April 201 5, at www.dailykos.com/story/2015/ 4/28/1 $380977 /$-Dear-White-America-Please-Stop-Talking-About-Martin-Luther-King-Jrand-the-Baltimore-Riots.

${ }^{23}$ See Algernon Austin, "It's Time to Stop Whitewashing Civil Rights History," Huffington Post, 4 Feb. 2016, at www.huffingtonpost.com/algernon-austin/its-time-to-stop-whitewas_b_9158710.html; Avlon; DeVega; Kali Holloway, "9 MLK Quotes the Mainstream Media Won't Cite," Alternet, I 6 Dec. 2015 , at www.alternet.org/civil-liberties/riotlanguage-unheard-9-mlk-quotes-mainstream-media-wont-cite; Kai Wright, "Dr. King, Forgotten Radical", American Prospect, 4 April 2008, http://prospect.org/article/drking-forgotten-radical. $\quad{ }^{24}$ Shakespeare, The Merchant of Venice, I.3.1 54-55. 
wrongs committed against him and a clearly stated plan for retribution, directed at Antonio's friends in a public street. ${ }^{25}$ Shylock then goes directly to the Duke to "impeach the freedom of the state, / If they deny him justice" 26 before finally demanding in court that the terms of the contract be fulfilled. ${ }^{27}$

However inhuman his demand for Antonio's flesh, Shylock is clear and rational in conveying why he feels he is owed it. Nevertheless, his motives are subject to willful misinterpretation; Venice's Christians are convinced they alone know his true intentions. In their first encounter, Antonio compares Shylock to a "goodly apple rotten at the heart," ${ }^{28}$ while the Duke assumes Shylock's display of vengeance is all for show. Antonio likens the impossibility of "soften[ing]" Shylock's "Jewish heart" to preventing the wolf's hunger or the waving of storm-tossed trees, as if his cruelty is similarly a matter of nature rather than something for which Antonio is, at least in part, responsible. ${ }^{29}$ When Shylock refuses to give any motive other than "a lodged hate and a certain loathing / I bear Antonio," Bassanio responds, "This is no answer, thou unfeeling man, / To excuse the current of thy cruelty," as if he was not already aware of his reasons, having been present for the conversation when Shylock enumerated Antonio's abuses against him. ${ }^{30}$ While the phrase "bound to" in the sense of "likely to" post-dates the play by about two and a half centuries, one could imagine it an appropriate use in Shylock's response, "I am not bound to please thee with my answers": ${ }^{31}$ whatever he says is not bound to sway the court's opinion of him, given that the Duke has declared him "an inhuman wretch, / uncapable of pity" before the trial even begins. ${ }^{32}$ The Christ-like passivity embodied by Antonio and espoused by Portia only permits Shylock to suffer in silence; even after he has acquiesced to giving up his revenge, his property, and his faith, Portia demands he give up his voice, reducing him to an obedient echo of the state: "Art thou contented, Jew? what dost thou say?" "I am content." 33

The advances made during the civil rights era owe much to the movement's deft use of communication through words and images. Written and oral addresses served to air grievances, justify the steps taken, and inspire those fighting for change; public demonstration through boycotts, sit-ins, and marches drew attention to their cause; television and newspaper media were employed to spread the message and alert the public to the horrors of lynching, segregation, and police violence. The movement's participants, however, are

25 Ibid., 3.1.53-73.

${ }^{26}$ Ibid., 3.2.278-79.

27 The public nature of Shylock's protest is made more apparent by comparison to Shakespeare's more conventional revengers; Hamlet and Titus primarily discuss their desire for revenge in private spaces, and their attempts to expose the rulers' crimes before their courts - Hamlet with The Mousetrap, Titus with his letters to the gods - are erratic and theatrical rather than straightforward.

${ }^{28}$ Shakespeare, The Merchant of Venice, I.3.101.

${ }^{30}$ Ibid., 4.1.0-61, 63-64. ${ }^{31}$ Ibid., 4.1.64-65.

${ }^{32}$ Ibid., 4.1.4-5.

29 Ibid., 4.1.79-80.

33 Ibid., 4.1.393-94. 
rarely given proper credit for the finesse required to successfully convey their message; instead, critics and supporters alike misrepresent their accomplishments as impulsive, emotional reactions rather than planned, targeted actions. At the time of the protests, civil rights activists were demonized as aggressive, angry agitators; in the time since, well-intentioned efforts to appeal to a sense of shared humanity condescendingly disregard the political savvy behind the protesters' methods. Rosa Parks is remembered as a seamstress too tired to change her seat after a long day at work rather than an NAACP secretary with a decade's experience in activism; King's words, more famous now than his actions, are taken out of context to portray him as an earnest father seeking to dismantle racism with the simple plea to see "little black boys and black girls ... join hands with little white boys and white girls as sisters and brothers." ${ }_{4}$ With King's legacy reduced to his antiracist feelings, any action, however nonconfrontational, is seen as "extreme" by comparison.

Racial-justice activists of recent years have built on their predecessors' work, using modern technology and social media to record and publicize acts of police brutality, broadcast their message, and unite local organizations in disparate geographic locations under common goals. The pattern of misinterpretation persists, however; public response to Kaepernick's actions echoes Venice's refusal to acknowledge Shylock's motives. Kaepernick clearly articulated his purposes in an interview after the first time his refusal to stand garnered attention, asserting, "I am not going to stand up to show pride in a flag for a country that oppresses black people and people of color ... There are bodies in the street and people getting paid leave and getting away with murder." 35 Lahren states in the Daily Show interview, "I'm not sure what oppression he's discussing ... I don't see what he's protesting, I would like to know exactly what he's protesting," even though she quoted his postgame statement word-for-word in her initial criticism. ${ }^{36}$ Although Kaepernick's criticism clearly focusses on the law-enforcement and justice systems rather than on white people as a group, critics used photographs of Kaepernick with his parents, who are white, to mock the notion of his being "oppressed by white people." 37 And though his choice to kneel rather than sit was purposefully chosen to show respect for members of the armed forces while still criticizing the justice system, widespread belief persists that his and other players' refusal to stand is intended to insult the military.

${ }^{34}$ Martin Luther King Jr., "I Have a Dream,” National Archives, at www.archives.gov/files/ press/exhibits/dream-speech.pdf, 5 .

35 Quoted in Steve Wyche, "Colin Kaepernick Explains Why He Sat during National Anthem," NFL.com, 27 Aug. 2016, at www.nfl.com/news/story/oap3000000691077/ article/colin-kaepernick-explains-protest-of-national-anthem.

${ }^{36}$ Lahren, interview with Trevor Noah.

37 "Brilliant Meme DESTROYS Racist 49ers QB with 5 BRUTAL Words," at www. americasfreedomfighters.com/2016/08/28/brilliant-meme. 
Lahren further attempts to discredit Kaepernick's stance by pointing out his financial success: "Maybe you should also decline the paycheck from the white owner of your team or the white fans who buy your merchandise and fill the stands to watch you play." ${ }^{38}$ This sentiment also surfaces in the tensions between Shylock's social marginalization and economic privilege; though Shylock is no greedier than the play's Christians and repeatedly refuses substantial reward in lieu of vengeance, critics and audiences alike find that "even the purity of Shylock's vengeance is sullied by associating it with money." ${ }_{9} 9$ The notion that wealthy individuals have no right to speak out against injustice that affects themselves or others - or that, like Shylock, celebrity artists and athletes should stick to playing a role that serves capitalism - is a common silencing technique (consider the Dixie Chicks, George W. Bush, and "Shut Up and Sing"; Donald Trump's tweeted response to the Women's March, "Celebs hurt cause badly"; and Saturday Night Live's response to Beyoncé's Super Bowl performance, the sketch "The Day Beyoncé Turned Black"40).

Perhaps what most chills us about The Merchant of Venice's treatment of Shylock is the ease with which he disappears. Other than a brief mention of Lorenzo and Jessica's inheritance from "the rich Jew," "4i he vanishes from the play in the last act; Portia and Bassanio quarrel about rings with no mention of the man whose dignity Portia sacrificed to ensure her husband's good behavior. Such indifference brings to mind a shirt Kaepernick was photographed wearing in late 2016: "WE MARCH, y'all mad. WE SIT DOWN, y'all mad. WE SPEAK UP, y'all mad. WE DIE, y'all silent." 42

\section{AUTHOR BIOGRAPHY}

Jessica Walker is an Assistant Professor of English at the University of North Georgia, where she teaches courses in Renaissance literature. Her published and forthcoming work primarily focusses on engaging marginalized student populations in early British literature courses and examining how medieval and early modern resonances surface in contemporary pop culture texts. She is Associate Editor of Educating English Daughters: Late Seventeenth-Century Debates.

${ }^{8}$ Tomi Lahren, "Kaepernick Has the First Amendment Right to Expression and so Do I" (29 Aug. 2016), at www.facebook.com/TomiLahren/videos/I063 I 23907 I I 4 I 29.

39 Nathan quoted in James O'Rourke, "The Guilty Pleasures of Bigotry: Ethnic Stereotypes in Trevor Nunn's Merchant of Venice and Dave Chappelle's Pixie Sketches," Shakespeare, I 2 , 3, 287-99, 295 .

40 "The Day Beyoncé Turned Black," Saturday Night Live, I 3 Feb. 2016, at https://youtu.be/ ociMBfkDG iw.

${ }^{41}$ Shakespeare, The Merchant of Venice, 5.1.292.

${ }^{42}$ Melaninvibez40o, photograph of Colin Kaepernick (I 8 Dec. 2016), at www.instagram.com/ p/BOlJYhbBGAx. 